\title{
AMBIGUOUS STRUGGLE: ABJECTING THE M/OTHER IN “AS I EBB’D WITH THE OCEAN OF LIFE"
}

\author{
Beth JENSEN
}

"EVERYTHING WAS FEMALE to him: even himself. [. . .] Always wanting to merge himself into the womb of something or other." So D. H. Lawrence describes Walt Whitman in Studies in Classic American Literature, published in 1923. Whitman, according to Lawrence, longs for the "great merge into the womb" (169); he longs to "stay in the flesh," "the belly," and "the breast" (172). In his essay, Lawrence taps into a vein that runs throughout Whitman's canon as he acknowledges the maternal presence that permeates Leaves of Grass. He does not narrowly define "mother," however. In fact, Whitman's mothers "needn't have had faces at all" (167). They may not even be female: Whitman would merge with "anything, so long as he could merge himself" (168). Lawrence also contends that nature, for Whitman, represents "one great function," reproduction (168). Even though Lawrence does not use an exact vocabulary to define the maternal force in Whitman's canon, his work serves as a precursor to the theoretical concepts developed by psychoanalytic theorist Julia Kristeva in the latter part of the twentieth century. Like Kristeva, Lawrence never limits "mother" to biological mother; instead, his description of the maternal presence in Leaves of Grass suggests the figure of the "M/other," the "psychoanalytical M/other," as Kristeva defines it in La Révolution du langage poétique (1974; translated as Revolution in Poetic Language). ${ }^{3}$ In Kristevan theory, the "M/other" looms large in the child's earliest phase of development, a "pre-Oedipal" phase, a phase that predates the Freudian Oedipal crisis. Neither the "M/other" nor the child has any specific identity or gender. They simply exist as one in a symbiotic union during this early phase of development. Likewise, in Lawrence's essay, mothers lack identity; they are faceless "muscles and wombs" (167). Even gender distinctions evaporate: "everything was female to him," Lawrence writes, "even himself" (168).

Critics have offered numerous historical ${ }^{4}$ and theoretical ${ }^{5}$ readings of Whitman's work since Lawrence's analysis, yet few emphasize the intense maternal presence he alludes to in his essay. Recent criti- 
cism often focuses on male sexuality and desire. Since the 1970 s, in fact, critics often discuss Whitman's poetry as a direct expression of homoeroticism. ${ }^{6}$ Even though articles acknowledging female sexuality ${ }^{7}$ in Leaves of Grass have increased over the past decade, few focus on the psychoanalytical "M/other" as Kristeva defines it. As a linguist, Kristeva discusses the maternal role in language acquisition and subject formation. Rather than focusing on the Father/son dynamic, she emphasizes the $\mathrm{M} /$ other/child dyad. When the child acquires language, the dyad is shattered, yet the child maintains on some unspoken level an intense desire to return to the pre-Oedipal union. As the child develops, it also experiences "abjection," a repulsion towards elements associated with the maternal body. Lawrence notes the gruesome images that dominate many of Whitman's poems, yet he cannot explain their significance other than to describe them as "a certain horrible pottage of human parts," containing "a certain ghoulish insistency" (163). He writes that "Walt's great poems are really huge fat tomb-plants, great rank graveyard growths" (165). Kristeva, on the other hand, provides the vocabulary to interpret these "ghoulish," lurid images. ${ }^{8}$

Before maternal separation occurs, Kristeva contends that the child, the pre-subject, wishes for nothing since all its desires are satisfied in its primal union with the $\mathrm{M}$ /other. It experiences sensation only, specifically jouissance, an extreme orgiastic pleasure associated with the maternal body. During this early idyllic existence, it has no sense of self since boundaries separating it and the $\mathrm{M} /$ other do not exist. As the primitive self moves towards language, it continues to yearn for the early Edenic union with the M/other. Subconsciously, this desire creates within the child confusion since its own existence is based on separation from the M/other: to desire her is to desire its own annihilation. Kristeva believes that fear and horror are intertwined with desire in this complex relationship as the child, in the process of separating from the M/other, experiences "abjection." Before the Father intervenes, the pre-subject begins to expel or to reject the $\mathrm{M} /$ other, associating her with those things that incite horror and repulsion, such as waste, filth, and dung, a necessary step since paternal intervention alone cannot ensure separation. The nausea and horror the future subject experiences in its encounter with the "abject," the "cast off," hint at its earliest effort to separate from the M/other in its movement towards language and culture; the nausea and the horror signal the initial revulsion towards the M/other, which in turn creates that first fragile sense of "I."

Ironically, abjection, a symptom of boundary-formation, incites horror, which could be defined as an anxiety about the absence of boundaries, a threat to the integrity of the developing "I." This horror can temporarily freeze the pre-subject in its movement towards the Symbolic (in Kristeva, Law, language, and culture), which creates within it the ambiguous feelings of desire and fear: desire for the former idyllic 
existence with the primal M/other and fear of "self" annihilation. These ambivalent feelings ultimately are associated not only with the M/other but with all maternal figures and images suggestive of this former union. Inevitably, as the pre-subject progresses in its development, the M/otherchild dyad disintegrates, creating within the emerging self both desire for and fear of the maternal body. As this chasm widens, she becomes the threatening "other." As Kristeva's theory predicts, the child experiences this as the abject. The encounter with the abject allows the child to create its first separate space, leading ultimately to its entrance into language and culture.

Experiencing the horror of the abject moves the pre-subject towards repression, a necessary step since boundaries separating the "I" from the "not I" must exist in the Symbolic. The subject's anxiety about borders and materiality resurfaces, however, when it encounters the grotesque. According to Kristeva, an encounter with the abject rekindles within the subject its earliest attempt "to release the hold of maternal entity"; the abject reminds the pre-subject of the constant risk of "falling back under the sway" of a maternal "power as securing as it is stifling." During this development, the child experiences confusion since it desires both union with and separation from the M/other. Its existence is uncertain since the chaos lurking just beyond the border could at any time engulf it, obliterating any sense of self. This struggle explains the "ambivalence" and "ambiguity" the child experiences in its development (Powers, 62): on one hand, the primitive self desires the sensuous, nurturing realm of the primal $\mathrm{M} /$ other while, on the other, it fears "self" annihilation. The child associates these ambivalent memories of the $\mathrm{M} /$ other with all maternal figures and images, including death, or in Kristevan terms, the abject. Kristeva writes in Powers of Horror that "what we designate as 'feminine,' far from being a primeval essence, will be seen as an 'other' without a name" (58-59). The emerging subject will encounter the $\mathrm{M} /$ other that it must repress in order to enter the Symbolic world of language, yet the primal $\mathrm{M}$ /other evokes both fear and pleasure since her realm, the Semiotic (in Kristeva, the body, the imagination, and the irrational) is dominated by both pre-identity and pleasure.

Kristeva's definition of the abject is reinforced by Freud's definition of Taboo: 'To us it means, on the one hand, 'sacred,' 'consecrated,' and on the other 'uncanny,' 'dangerous,' 'forbidden,' 'unclean."'10 The taboo suggests the "unapproachable," something that is "principally expressed in prohibitions and restrictions" (Totem, 13:18). Freud asserts that one's need to reject the taboo for social propriety is inexplicable since the origin of the taboo is unknown. He posits his definition of the taboo on murder, specifically patricide, rather than on incest, a choice Kristeva criticizes in Powers of Horror. Disagreeing with Freud's contention that a taboo such as incest has no known origin, Kristeva revises 
Freudian theory as she argues that the fear of incest is founded on one's fear of the abject, in essence equating the two terms. For Kristeva, taboo, abject, and woman are intertwined, inseparable. The taboo and the abject are socially unacceptable, and since woman is inextricably linked with the abject, she too is marginalized. Yet the abject and its associations with the $\mathrm{M}$ /other can never be completely repressed, a point Kristeva makes when she writes that tension remains between the Semiotic and the Symbolic even after the formation of the "I." They remain inter-dependent, creating a subject that is always en procès, "in process/on trial." Consequently, the speaking subject will continue to experience, to varying degrees, the influence of the Semiotic, expressed, at times, in a subtle but undeniable longing for the $\mathrm{M} /$ other. If the subject wishes to remain socially acceptable, however, it must attempt to suppress the M/other, a feat not easily accomplished since the "taboo" represents, according to Freud, the "oldest and most powerful of human desires" (Totem, 13:32).

Whitman's 1860 poem "As I Ebb'd with the Ocean of Life"11 begins to manifest the pull of the Father towards the Symbolic. Whitman's persona, henceforth known as "the poet" or "the speaker,"12 is repulsed by elements Kristeva associates with the abject. His response to corporeal images suggests a movement away from the $\mathrm{M} / \mathrm{other}$, a dramatic shift from the earlier editions of Leaves of Grass. In poems first published in 1855 and 1856, the poet openly celebrates various unions reminiscent of the early phase of child development as he emphasizes the sexual ecstasy he feels in his interactions with the maternal presence. A representative example occurs in "Song of Myself" as the poet immerses himself in the maternal ocean's "billowy drowse." 13 Intoxicated with her "honeyed morphine," he rushes naked into the waves, since he wants nothing more than to lose himself in her "amorous wet." The maternal figure is both mother and lover as the poet emphasizes her reproductive capability and her sexuality.

$\mathrm{He}$ also embraces disease and carrion in the first two editions when he encounters them; abject elements do not repulse him as they will in 1860. In the 1855 poem eventually entitled "Song of Myself," the corpse does not frighten or offend him: "And as to you corpse I think you are good manure, but that does not offend me, / I smell the white roses sweetscented and growing, / I reach to the leafy lips. ... I reach to the polished breasts of melons" (1294-1296). ${ }^{14}$ His celebration includes the sick and the dying: the "lunatic," the "malformed limbs," the "opium eater," and the prostitute with her "tipsy and pimpled neck" ("Song of Myself," 273; 277; 304-305). He even champions the remains of his own body, joyfully becoming the residue and dirt he will reject in 1860: "I bequeath myself to the dirt to grow from the grass I love, / If you want me again look for me under your bootsoles" ("Song of Myself," 13391340). Likewise, in "This Compost" (1856), ${ }^{15}$ he celebrates the grass, 
the lilacs, and the apple-buds that burst forth from "strata of sour dead," "distempered corpses," and "foul meat" $(9 ; 16 ; 30)$, and he willingly bathes in the sea, knowing that the water filled with "fevers" will "not endanger" him $(41 ; 35)$. He praises the "naked meat" of the body, celebrating its "lung-sponges," "stomach-sac," and "bowels sweet and clean" in "I Sing the Body Electric" (1855), ${ }^{16}$ and he becomes the shroud itself in "The Sleepers" (1855), enwrapping a corpse: "A shroud I seeand I am the shroud . . . I I wrap a body and lie in the coffin" (66). He embraces "the livid faces of drunkards, the sick-gray faces of onanists, / The gashed bodies on the battle-fields," the "insane," the "consumptive," the "erysipalite," the "twisted skull," "the watery or rotten blood," and the "child of the glutton or venerealee," since "they are all beautiful" ("The Sleepers," 8-9; 139, 157-158).

Even though the poet exists in harmony with the abject in 1855 and 1856, he does encounter, at times, maternal images that frighten him. He may embrace the corpse in "The Sleepers," yet glimpses of the terrible, abject mother emerge. The ocean, at times tumultuous and irrational, threatens his very existence, most notably in the vignette of the "beautiful gigantic swimmer." Totally immersed in water, the "gigantic swimmer" swims "naked through the eddies of the sea." $\mathrm{He}$ is not embraced, however, by mother ocean but instead is confronted by "slapping eddies." Violently expelled from the water/womb, the swimmer receives his first "slap" after the sea brutally forces him from her body: the "swift-running eddies [. . .] dash him headforemost on the rocks," and the water after this violent birth is "red-trickled" and "spotted with [. . .] blood" (74; 78). The waves "bear" him away, "roll him and swing him and turn him" until his body is "borne [born?] in the circling eddies," continually "bruised on rocks" (78-79). Yet the poet does not want to separate himself from the M/other, no matter how tempestuous she may be: "I turn but do not extricate myself" (81). He acknowledges that he is "confused," yet he wants to remain "with darkness" (82).

In the vignette that follows, the poet again sees the violent force of mother nature as the beach is "cut by the razory ice-wind" (83). Momentarily, nature attempts to deceive him as "the tempest lulls and the moon comes floundering through the drifts" (84). Mother nature's soothing "lulls," however, are fleeting. Soon, he hears the helpless ship burst on the rocks and the "howls of dismay" as the wind and the ocean batter the ship against the shoreline. He runs to the ocean's edge where the freezing surf drenches him: "I can but rush to the surf and let it drench me and freeze upon me" (87). As Anne Williams notes, ice has metaphorical implications, a theory she applies to "The Rime of the Ancient Mariner": "A familiar metaphor for rejection, ice is an apt figure for the transformation of good mother into bad: the tropically warm, liquid medium hitherto supporting the ship turns hard and frigid, frustrating 
(e)motion." 17 As the water turns to an icy spray in "The Sleepers," the poet cannot immerse himself in the ocean. Again, he encounters the "terrible mother." This rejection continues after the bodies of the dead are washed ashore by the ocean's waves. He retrieves nature's offspring and places them in their cribs: "not one of the company is washed to us alive; / In the morning I help pick up the dead and lay them in rows in a barn" (88-89).

Even though these encounters with the M/other are frightening in 1855 , the poet ultimately returns within "The Sleepers" to maternal images that soothe him, evidenced in the closing lines of the poem as he embraces mother night: "I stay awhile away $\mathrm{O}$ night, but I return to you again and love you" (178). He acknowledges that he will "not desert her in whom" he "lay so long" (181). In the dark recesses of the unconscious, the M/other/child dyad is restored: "I will stop only a time with the night, and rise betimes, / I will duly pass the day $\mathrm{O}$ my mother, and duly return to you" (183-184). Even the "beautiful lost swimmer," once brutalized by the ocean, is restored in the surreal world of the sleepers: "the night and sleep have likened them and restored them" (143). Ultimately, all will unite in the "clean womb cohering" (152).

In the 1860 edition, however, the maternal presence offers no comfort to the poet. Instead, his desire for the M/other is tempered by his fear of her. The "ghoulish," "horrible pottage of human parts" Lawrence alludes to in his essay now threatens the poet when he encounters it. In the 1860 "A Hand-Mirror," he peers into the "looking-glass" only to be repulsed by what he sees: "Outside fair costume-within ashes and filth" (2). As he looks at his reflection, he sees lungs "rotting away piecemeal, stomach sour and cankerous, / Joints rheumatic, bowels clogged with abomination," and blood circulating in "dark and poisonous streams" (6-8). His reflection is not a unified image; instead, it is the "unwholesome eater's face" and the "venerealee's flesh" (5). He rejects his earlier works, referring to them as "babble" (9). ${ }^{18}$ In "Trickle Drops," also published in 1860 , his bloody tears "Stain every page, stain every song" and "every word": "Glow upon all I have written or shall write, bleeding drops,/ Let it all be seen in your light, blushing drops" (7; 10-11). He suggests that the future reader will reject his work, condemning all that he has "written or shall write" (10). This revulsion towards the abject corresponds with the pre-subject's first effort to separate from the $\mathrm{M} /$ other, allowing it to create its first separate space. As the speaker progresses toward the Symbolic in the 1860 edition, he begins to acknowledge social restrictions as he shuns anything associated with materiality (matter/mater), including bodily waste and rotting flesh. $\mathrm{He}$ now responds with horror to the corporeal images he embraced in 1855 and 1856 as he rejects the M/other and the grotesque images he associates with her. It is with this repudiation that he struggles since his en- 
counters with the abjected $\mathrm{M} /$ other are both fearful and pleasurable. $\mathrm{He}$ desires, in essence, the abject.

In "As I Ebb'd with the Ocean of Life," the poet experiences dejection and isolation as he wanders alone along the seashore on an autumn day. He precariously walks the boundary separating the land from the ocean, a boundary that fascinated Whitman throughout his life. In Specimen Days, he describes this junction that separates the solid from the liquid with terms suggestive of the Semiotic:

Even as a boy, I had the fancy, the wish, to write a piece, perhaps a poem, about the seashore - that suggesting, dividing line, contact, junction, the solid marrying the liquidthat curious, lurking something, [. . . . . I remember well, I felt that I must one day write a book expressing this liquid, mystic theme. Afterward, I recollect, how it came to me that instead of any special lyrical or epical or literary attempt, the sea-shore should be an invisible influence [. . .]. ${ }^{19}$

The struggle for the future self erupts at this "junction," this ambiguous "dividing line" where land and water meet as the speaker begins to move towards the land and the Father: "You friable shore, with trails of debris! / You fish-shaped island! I take what is underfoot; / What is yours is mine, my father" (38-40), yet he continues to experience the overwhelming draw towards the ocean and the M/other: "Ebb, ocean of life, (the flow will return,) / Cease not your moaning, you fierce old mother, / Endlessly cry for your castaways-but fear not, deny not me, / Rustle not up so hoarse and angry against my feet, as I touch you, or gather from you" (51-54). On one side, he sees the land, while on the other, the ocean, yet it is not the visual image but rather the "sound of breaking waves" that reminds him of that early union, that "old thought of likenesses," when no distinct borders existed between M/other and child and the eye/I had yet to form. In Sexual/Textual Politics, Toril Moi describes this positioning of the "other":

If patriarchy sees women as occupying a marginal position within the symbolic order, then it can construe them as the limit or borderline of that order. From a phallocentric point of view, women will then come to represent the necessary frontier between man and chaos; but because of their very marginality they will also always seem to recede into and merge with the chaos of the outside. ${ }^{20}$

As the "sea-ripples wash" over the beach and blur the lines of demarcation between land and ocean, the poet looks at the "sediment" that accumulates in his foot's imprint in the sand, the point where land and water meet: "[I] Was seized by the spirit that trails in the lines underfoot, / In the rim, the sediment, that stands for all the water and all the land of the globe" (9-10). He sees the ocean's debris as "sediment," worthless residue forming along the seashore. Mother ocean is no longer soothing and inviting; instead she is "fierce" and "old." She 
stings and darts at "her castaways" as her waves "rustle up, hoarse and sibilant," creating within her child a sense of isolation and rejection (45). As the speaker's sense of self, his "eternal self," develops, his union with the M/other begins to crumble, leaving him bewildered and dejected. Soon after acknowledging the existence of this "self" twice within the first seventeen lines of the poem, he is "seized" by the residue that the "fierce old mother" leaves at his feet:

Fascinated, my eyes, reverting from the south, dropped, to follow those slender winrows, Chaff, straw, splinters of wood, weeds, and the sea-gluten,

Scum, scales from shining rocks, leaves of salt-lettuce, left by the tide; [. . .]

When he sees the scum, scale, weeds, and sea-gluten, residue Kristeva would associate with the abject, his eyes/I do not completely close; instead, they only "dropped" as he looks at what the fierce old mother has thrown up on the beach, her "castaways," debris with which he himself will soon identify.

His confusion and bewilderment escalate as the shores feel alien to him, the ocean mysterious: "As I wend the shores I know not, / [. . . As the ocean so mysterious rolls toward me closer and closer, / At once I find, the least thing that belongs to me, or that I see or touch, I know not; [. . .]" (18; 21-22). He also hears voices, suggestive of the spoken word and its associations with the Father, yet these voices are "wrecked." At this point, he is ill at ease straddling the border separating land from water. His ambiguous feelings towards the land and the ocean suggest the struggle the pre-subject experiences as it moves from the Semiotic to the Symbolic. In her essay "Freud and Love: Treatment and Its Discontents," Kristeva describes this struggle as the "Ego painfully attempt[ing] to come into being" (257). ${ }^{21}$ She writes that the emerging subject "must engage in a struggle with the imaginary mother" before it can anchor itself in language (257).

As the struggle ensues in "As I Ebb'd," the speaker describes himself as one of the M/other's castaways: "I, too, but signify, at the utmost, a little washed-up drift, / A few sands and dead leaves to gather" (22-23). Yet his longing to merge with the M/other is still apparent when he expresses his desire to "gather, and merge, myself as part of the sands and drift," all along inhaling "the impalpable breezes that set in upon" him $(24 ; 20)$. As he moves toward the Father, he cannot readily release his grip on the $\mathrm{M} /$ other. He does begin, however, to associate the maternal with the abject, an essential step, Kristeva contends, in the emerging ego's development. In this early formation of the "I," the future subject often feels nausea, horror, and revulsion, terms one could use to describe the poet's feelings in "As I Ebb'd with the Ocean of Life": 
Me and mine!

We, loose winrows, little corpses,

Froth, snowy white, and bubbles,

(See! from my dead lips the ooze exuding at last!

See-the prismatic colors, glistening and rolling!)

Tufts of straw, sands, fragments, [...] . (57-61)

From a Kristevan perspective, the poet rejects his own materiality as he approaches the Father, finding his own body and what it produces nothing more than trash: "I, too, but signify, at the utmost, a little washed-up drift" (22). He begins to question the worthiness of his own songs as he moves toward the Symbolic, feeling marginalized, "Oppressed" since he has "dared to open" his "mouth," producing "blab" rather than the linear line of patriarchal language:

O baffled, balked,

Bent to the very earth, here preceding what follows,

Oppressed with myself that I have dared to open my mouth,

Aware now, that, amid all that blab whose echoes recoil upon me, I have not once

had the least idea who or what I am,

But that before all my insolent poems the real ME still stands untouched, untold, altogether unreached,

Withdrawn far, mocking me with mock-congratulatory signs and bows,

With peals of distant ironical laughter at every word I have written or shall write,

Striking me with insults till I fall helpless upon the sand. (25-31)

Experiencing abjection as he looks upon his own waste, his "little washedup drift," he sees in the distance "mock-congratulatory signs and bows" and hears "peals of distant ironical laughter" emanating from "the real $\mathrm{Me}$," his future "self" who stands "untouched, untold, altogether unreached." According to Kristevan theory, the avant-garde writer does not "distance himself from what he writes," but instead "speaks from within horror." 22 Likewise, the speaker in "As I Ebb'd with the Ocean of Life" does not distance himself from his work; he actually becomes his work, identifying both himself and his earlier songs as "washed-up drift." The "apocalyptic laughter" Kristeva describes, suggested by the "peals of distant ironical laughter" in "As I Ebb'd with the Ocean of Life," is the avant-garde poet's response to his direct encounter with the abject:

So his laughter bursts out, facing abjection, and always originating at the same source, of which Freud had caught a glimpse: the gushing forth of the unconscious, the repressed, suppressed pleasure, be it sex or death. (Kristeva, Powers, 205-206)

As the distant self points to the debris and sand and then to "these songs," the poet in his movement towards the Symbolic is forced to see his work as "scum, scales" and "sea-gluten," a sight the emerging self would not want to see, at least not consciously. John Lechte notes that 
"the speaking being" experiences the contradictory emotions of horror and fascination when it encounters the abject: "How can the speaking being cope with such a contradiction? Kristeva's answer is: not by more repression, but through a kind of laughter [. . .] : an apocalyptic laughter, given that we are faced with abjection" (Fulia Kristeva, 167).

As the self develops, the poet becomes acutely aware of his deviation from patriarchy's norm, both in his form of expression and, as suggested in the Calamus poems, his sexuality, resulting in feelings of alienation and isolation. He is left wondering how he "dared to open" his "mouth to sing at all." As David Leverenz notes in Manhood and the American Renaissance, Whitman along with other nineteenth-century male writers "felt self-consciously deviant from prevailing norms of manly behavior," norms that were imposed by the patriarchal "gender ideologies in the American marketplace." 23 Leverenz also notes that during the American Renaissance literature was often written by women for women, increasing the male author's sense of alienation:

Another inducement to alienation and nonconformity for male writers was their awareness that the audience for serious literature was shifting from patrician men of public affairs to middle class women, from men in power to women at the leisured margin of power. (15)

Feeling rejected, the speaker longs to fall into the soothing, sensuous arms of mother nature as he did in 1855. Instead, she stings him: "Nature here, in sight of the sea, is taking advantage of me, to dart upon me, and sting me" (33).

Even though the poet mentions father figures in earlier poems, ${ }^{24}$ he directly addresses the Father for the first time in 1860:

You friable shore, with trails of debris!

You fish-shaped island! I take what is underfoot;

What is yours is mine, my father.

I throw myself upon your breast, my father,

I cling to you so that you cannot unloose me,

I hold you so firm, till you answer me something.

Kiss me, my father,

Touch me with your lips, as I touch those I love,

Breathe to me, while I hold you close, the secret of the wondrous murmuring I envy,

For I fear I shall become crazed, if I cannot emulate it, and utter myself as well as it.

(38-40; 45-51)

This emphasis on the Father in "As I Ebb'd" has produced several readings centering on the paternal presence. Tenney Nathanson, for example, focuses on the "paternal metaphor" within the poem. ${ }^{25}$ Very 
much like Edwin Haviland Miller and Michael Moon, ${ }^{26}$ Nathanson places the male figure, in this case the Father, at the center of the text. Even though these critics acknowledge the maternal role in Whitman's poetry, the male figure dominates their readings with the M/other assuming an ancillary position. It is the Father, according to Nathanson, who is asked both to intercede between the poet and paternal law and to restore the poet's relation to the mother. Kristevan theory, on the other hand, allows for a maternal-based reading. The child both desires and rejects the $\mathrm{M} / \mathrm{other}$. To reject the source that once provided sustenance, suggested by the image of the breast, the child must associate the $M$ / other with the abject, an essential step in subject formation. Nathanson also writes that both the "poet's voice and speech" and his "identity" have been "purloined at the poem's close" (466). Using Kristeva's theory of language acquisition, I contend that the poet in "As I Ebb'd" progresses, albeit painfully, in his development of self. He is not losing identity but rather acquiring it. In the process of achieving identity, he abjects and ultimately rejects the $\mathrm{M} /$ other. When his efforts to create a surrogate $\mathrm{M}$ /other fail, he experiences isolation and dejection. From this perspective, "As I Ebb'd" suggests a maternal rather than a paternal metaphor.

As the poet moves toward Law, language, and culture, his overt sexual desire for the $\mathrm{M} /$ other vanishes. Fouissance, the erotic pleasure he experiences in his union with the maternal body in the first two editions, now places him at risk of marginalization. To avoid this, he must align himself with the Symbolic, rejecting his "blab." Yet in his encounter with the Father, he does not ask for the "Word," the symbol of patriarchy, as he will in "Out of the Cradle Endlessly Rocking." Instead, he asks the secret of the "murmuring," muffled, jumbled sounds rather than clearly spoken words. He still walks along the "friable shore" with its disintegrating border, listening to the murmuring ocean. $\mathrm{He}$ attempts to assuage his anxiety by presenting the Father as a comforting, "maternal" entity as he throws himself upon the Father's "breast." The maternalized Father, however, is not a soothing figure in "As I Ebb'd." Even though the poet attempts to transform the paternal land into a maternal figure, creating a surrogate mother who will pull him to "her" breast to kiss and to comfort him, he fails. The Father ultimately represents society, culture, those "peals of distant ironical laughter" that will ridicule and reject the poet's song. The Father is God the Father; the Law of the Father: stern images that will never soothe the poet as the maternal ocean does in the first two editions when she rocks him her in billowy drowse and souses him with her amorous wet.

A harsh image of the Father also appears in the 1855 poem "There Was a Child Went Forth": "The father, strong, selfsufficient, manly, mean, angered, unjust, / The blow, the quick loud word," yet the mother, unmoved by paternal tyranny, soothes the child with "mild words" and 
"a wholesome odor falling off her person and clothes" (23-25). She does not hiss or dart at the child as she will in 1860. Some biographers suggest that the harsh portrayal of the father in Whitman's poetry is autobiographical, ${ }^{27}$ yet Jerome Loving negates this point in his recent biography of Whitman: "There is strong evidence from personal rather than literary sources that Walt Whitman, Sr., was much loved by his son." ${ }^{28}$ Loving's comment suggests that a strict biographical reading of the paternal role in Whitman's poetry may be overstated. From a psychoanalytical perspective, however, the Father cannot be soothing since he ultimately disrupts the blissful symbiosis between $\mathrm{M} /$ other and child.

In many ways, "As I Ebb'd" and "Out of the Cradle" serve as bookends to the 1860 edition: "As I Ebb'd" manifests the early pull of the child towards language and culture while "Out of the Cradle" presents the child's ultimate acceptance of the Word. Even in "Out of the Cradle," however, the ocean is threatening: she is the "fierce old mother" who is "incessantly moaning" and a "savage old mother" who is crying and "hissing." These disturbing images appear in both the 1860 and 1881 versions of the poem, but only in the revisions occurring after 1860 does the poet attempt to soften the harshness of the ocean. Only in later editions is the sea described as "laving" the poet "softly all over" and only in 1881 is she dressed in "sweet garments" rocking the cradle. With the addition of the penultimate line in 1881, "(Or like some old crone rocking the cradle, swathed in sweet garments, bending aside,)," the poem does move towards the Symbolic. If the ocean were not described at the conclusion dressed in sweet garments, rocking the cradle, the primal $\mathrm{M}$ /other would threaten the speaker, impeding his movement towards language and culture. These somewhat soothing, passive, non-sexual images of the $\mathrm{M}$ /other that emerge in the revisions suggest the changing role of the maternal in Whitman's poetry. Yet even now, ambiguity and uncertainty exist. The ocean may appear in her "sweet garments," "softly" laving the poet; yet she is a "hissing" "old crone," a threatening image of a withered, old hag.

Touch remains important in the 1860 edition as the poet clings to the Father, pleading for a kiss. The eroticism associated with touch in the earlier editions, however, vanishes. ${ }^{29}$ When the Father provides no comfort to the anxious speaker, he turns to the M/other, asking her not to "rustle [. . .] up so hoarse and angry" against his feet as he touches her tenderly:

Ebb, ocean of life, (the flow will return,)

Cease not your moaning, you fierce old mother,

Endlessly cry for your castaways - but fear not, deny not me,

Rustle not up so hoarse and angry against my feet, as I touch you, or gather from you.

I mean tenderly by you, [. . . . (51-55) 
Yet she too rejects him.

Images of rejection abound as the poet experiences abjection, an appropriate combination since "abject" means "to throw out." Debris, the controlling image throughout the poem, remains when the tide ebbs and serves as the stimulus for the speaker's thoughts. He identifies his body and his work with the chaff, straw, weeds, scum, and scale left behind by the ocean. He describes himself and all that mother ocean "abjects" as "castaways." He is rejected when he throws himself upon the Father's breast and when he walks into the M/other's water. He asks the M/other not to "deny" him, that is, not to reject or cast him out, yet she does when she stings and darts at him. And even his future self, representative of patriarchy, rejects him and his work, with mocking "peals of distant ironical laughter" at "every word" he has "written or shall write." He anticipates further rejection in the poem's concluding lines when he addresses future readers: "You, up there, walking or sitting, / Whoever you are-we too lie in drifts at your feet." Even the poet ultimately rejects his own "blab."

Kristeva writes in Powers of Horror of the most "elementary and most archaic form of abjection," food loathing. Her description of expulsion suggests a possible reading for the enigmatic lines focusing on rejection in "As I Ebb'd with the Ocean of Life." In the poem, the poet rejects his own work which he equates with his "self." Hence, he rejects, expels, himself just as the pre-subject does in Kristeva's theory of abjection:

Along with sight-clouding dizziness, nausea makes me balk at that milk cream, separates me from the mother and father who proffer it. "I" want none of that element, sign of their desire; "I" do not want to listen, "I" do not assimilate it, "I" expel it. But since the food is not an "other" for "Me," who am only in their desire, I expel myself, I spit myself out, I abject myself within the same motion through which "I" claim to establish myself [. . . . "I" am in the process of becoming an other at the expense of my own death. (Powers, 3)

Overwhelmed with rejection, the speaker now identifies "Me and mine!," his own body and what he has produced, as "little corpses." His own "dead lips" exude "ooze" rather than the "Word" as he describes himself as a corpse, a term Kristeva associates more than any other with the abject:

[...] refuse and corpses show me what I permanently thrust aside in order to live . [. . ] There, I am at the border of my condition as a living being. My body extricates itself, as being alive, from that border. Such wastes drop so that I might live, until, from loss to loss, nothing remains in me and my entire body falls beyond the limit - cadere, cadaver. If dung signifies the other side of the border, the place where I am not and which permits me to be, the corpse, the most sickening of wastes, is a border that has encroached upon everything. It is no longer I who expel, 'I' is expelled. (Powers, 3-4) 
Before the poet can speak the Word, the language of patriarchy, he must experience the abject, that which is cast-off. He begins to see himself and his poems as waste, vomit, "thrown" along the shoreline.

According to Kristeva, the child must establish borders between its "insides" and its "outsides" to become the speaking subject. In 1860, however, the immobilizing horror of the abject disrupts the boundary between the "I" and the "not I," as the poet equates himself and his work with the debris, the "washed-up drift" (22). In the poem, the water encroaches upon the shoreline, the barrier that protects the land and the emerging subject from the fierce old mother who "rustles [. . . ] up so hoarse and angry against" it (54). The ocean transgresses the border that separates patriarchy's "fish-shaped island" from "the storm," the "darkness, the swell," the "sobbing dirge of Nature" $(39 ; 63 ; 67)$. The abject mother, suggested in 1855, emerges in full force in 1860 .

In the patriarchal order, the M/other is lost when the Law of the Father offers the emerging subject identity. Yet the ambiguous feelings the speaker experiences in "As I Ebb'd with the Ocean of Life" suggest the conflicting desires both to reject and to return to the M/other, or in the words of D.H. Lawrence to "merge into the womb. Woman" (169). The subject may temporarily feel clean, removed from the abject, but as his yearnings suggest, he can never fully repress his desire, a point Madelon Sprengnether makes when she writes that the M/other, in "her disappearing act, [. . . evades and frustrates [. . .] [Freud's] attempts at grand theory at the same time that she lures him, like a fata morgana, into the mists of metapsychology." ${ }^{30}$ The M/other will inevitably return, like the ocean's tide, subtly and subversively, creating a subject who, as Kristeva says, is forever en procès.

\section{Gwinnett University Center}

\section{NOTES}

1 D.H. Lawrence, Studies in Classic American Literature (New York: Viking Press, 1969), 168.

2 I will use $\mathrm{M} /$ other, pre-Oedipal $\mathrm{M}$ /other, and primal $\mathrm{M}$ /other to describe the figure of the mother in the child's earliest phase of development.

3 Revolution in Poetic Language, trans. Margaret Waller, in The Kristeva Reader, ed. Toril Moi (New York: Columbia University Press, 1986), 90-136; abbreviated as Revolution.

4 Several critics discuss the historical role of the mother in Whitman's work: Arthur Wrobel, in "Noble American Motherhood: Whitman, Women, and the Ideal Democracy" (American Studies 21 [1980], 7-25), writes that Whitman's 
women must willingly submit to motherhood. M. Jimmie Killingsworth, in "Whitman and Motherhood: A Historical View" (American Literature 54 [1982], 28-43), concludes that the theme of motherhood in Whitman's poems is "decidedly Victorian" (42), while Harold Aspiz, in "Walt Whitman, Feminist" (Walt Whitman: Here and Now, ed. Joann Krieg [Westport, Connecticut: Greenwood Press, 1985], 79-88), contends that Whitman often reinforces the feminist rather than the sentimentalist view of women in the nineteenth century. Betsy Erkkila, in Whitman the Political Poet (New York: Oxford University Press, 1989), writes that Whitman's mothers do not exist as a wives in relation to individual husbands; instead, the poet "sought to remove motherhood from the private sphere and release the values of nurturance, love, generativity, and community into the culture at large" (259). Jerome Loving, focusing on female sexuality in "Whitman's Idea of Women" (Walt Whitman of Mickle Street: A Centennial Collection, ed. Geoffrey M. Sill [Knoxville: The University of Tennessee Press, 1994], 151-167), argues that Whitman's complete woman was a potential mother who acknowledged her "animal want" in an age that discouraged both recreational sex and female sexuality (152). Vivian R. Pollack, in "'In Loftiest Spheres': Whitman's Visionary Feminism" (Breaking Bounds, ed. Betsy Erkkila and Jay Grossman [New York: Oxford University Press, 1996], 92-111), examines Whitman's "feminism" and "antifeminism," noting that the poet reaffirms in much of his writing "the mid-nineteenth-century American cult of the mother" (92). Sherry Ceniza, in Walt Whitman and 19th-Century Women Reformers (Tuscaloosa: University of Alabama Press, 1998), notes that Whitman did not see "motherhood" as gender bound; she contends that few would have problems with Whitman's images of women if he had used the term "parentage" in place of "motherhood." See notes 5, 6, and 24 for additional comments on Whitman scholarship.

5 Edwin Haviland Miller's 1968 Freudian reading, Walt Whitman's Poetry: A Psychological fourney (New York: New York University Press, 1968), emphasizes Whitman's relationship with his father, describing "As I Ebb'd with the Ocean of Life" and "Out of the Cradle Endlessly Rocking" as Whitman's longing "for a meaningful male figure with whom to identify" (48) and "The Sleepers" as the adolescent's desire to "relive the oedipal conflict" with the father (75). In Whitman's fourneys into Chaos: A Psychoanalytical Study of the Poetic Process (Princeton: Princeton University Press, 1975), Stephen Black contends that the poems published between 1855 and 1865 represent the poet's attempt "to keep hidden from himself both his homosexual impulses and his sexual confusions" (5); "As I Ebb'd with the Ocean of Life" presents "those immutable facts of nature the poet desperately wants to escape: conception and death" (58). Donna Moder, "Gender Bipolarity and the Metaphorical Dimensions of Creativity in Walt Whitman's Poetry: A Psychobiographical Study” (Literature and Psychology 34 [1988], 34-52), focuses on the psychodynamics of the Whitman household, particularly the relationship between Whitman and his mother, Louisa, to explain the homoeroticism in the poet's work. Karen Oakes applies the theories of Nancy Chodorow in her discussion of Whitman's "repressed feminine voice" (181) in "I stop somewhere waiting for you': Whitman's Femininity and the Reader of Leaves of Grass" (Out of Bounds: Male Writers and Gender(ed) Criticism, ed. Laura Claridge and Elizabeth Langland [Amherst: 
University of Massachusetts Press, 1990], 169-185), arguing that Whitman's "feminine" voice defines itself in Leaves of Grass through relationships, most notably with the reader. Michael Moon, Disseminating Whitman: Revision and Corporeality in Leaves of Grass (Cambridge: Harvard University Press, 1991), writes that the speaker in "As I Ebb'd with the Ocean of Life" ascends to "the oedipalized male position" which places him "in a relationship to the figure of the father and the father's body" (145). Applying Lacanian theory, Steven A. Wartofsky in "Whitman's Impossible Mother" (Walt Whitman Quarterly Review 9 [1992], 196-207), contends that the "mother's tongue speaks through Whitman," articulating at times in the language of the patriarchal Other (200). Other times, however, the mother's tongue is the "unimaginable voice" that precedes articulation (199). The mother in "As I Ebb'd" speaks "her own desire" with cries and moans (206). In each instance, her voice remains "excluded from the realm of the Other," remaining the "other to the Other" $(206 ; 199)$. In "Leaves of Grass as a 'Woman's Book"' (Walt Whitman Quarterly Review 10 [1993], 195-208), Maire Mullins applies French Feminist Hélène Cixous's concept of "writing-the body," allowing for a more nuanced recognition of feminine eroticism in three of Whitman's poems - "Crossing Brooklyn Ferry," stanza eleven in "Song of Myself," and the woman's dream sequence in "The Sleepers"-and presents all three as examples of "l'écriture féminine." Eve Kosofsky Sedgwick, in "Confusion of Tongues," a chapter written in conjunction with Michael Moon in Breaking Bounds, suggests that Whitman's poetic voice presupposed his mother's presence within it as the force of that voice's powers of attachment. Daneen Wardrop, in "Whitman as Furtive Mother: The Supplementary fouissance of the "Ambushed Womb": in 'Song of Myself" (Texas Studies in Literature and Language, 10 [1998], 142-157), explores Whitman's use of the line "ambushed womb of the shadows" in "Song of Myself." The line suggests that the speaker himself will bear children, allowing him to gain the maternal power he needs to express the inexpressible. Eric Gray, in "Sexual Anxiety and Whitman's 'O Hot-Cheeked and Blushing"' (ATQ, 12 [March 1998], 5-26), offers a Freudian reading of the passage Whitman excluded in the 1881 version of "The Sleepers." See note 24 for Tenney Nathanson's discussion of the paternal metaphor in Whitman's canon.

6 A sampling of the titles of articles and books published since the late seventies suggests the heavy emphasis on male sexuality and desire: Robert K. Martin, The Homosexual Tradition in American Poetry (Austin: University of Texas Press, 1979); Harold Aspiz, "Walt Whitman: The Spermatic Imagination," American Literature 56 (1984), 379-395; Alan Helms, "Hints . . . Faint Clews and Indirections': Whitman's Homosexual Disguises," Walt Whitman Here and Now, 61-67; Joseph Cady, "Drum-Taps and NineteenthCentury Male Homosexual Literature," Walt Whitman Here and Now, 4959; Robyn Wiegman, "Writing the Male Body: Naked Patriarchy and Whitmanian Democracy," Literature and Psychology 34 (1987), 16-26; Michael Moon, Disseminating Whitman; Byrne R. S. Fone, Masculine Landscapes: Walt Whitman and the Homoerotic Text (Carbondale: Southern Illinois University Press, 1992); Christopher Newfield, "Democracy and Male Homoeroticism," Yale fournal of Criticism 6 (Fall 1993), 29-62; Betsy Erkkila, "Whitman and the Homosexual Republic," Walt Whitman: The Centennial 
Essays, ed. Ed Folsom (Iowa City: University of Iowa Press, 1994), 153171; Hershel Parker, "The Real 'Live Oak, with Moss': Straight Talk about Whitman's Gay Manifesto," Nineteenth-Century Literature 51 (September 1996), 145-160; Tom Yingling, "Homosexuality and Utopian Discourse in American Poetry," Breaking Bounds, 135-146. Gary Schmidgal, Walt Whitman: A Gay Life, (New York: Will Abrahams; Dutton, 1997). This list, of course, is not exhaustive, but it indicates a distinct pattern in Whitman scholarship.

7 See readings by Aspiz and Loving cited in note 4; Moon, Oakes, Mullins, and Wartofsky in note 5. Also see Carol Zapata Whelan's "'Do I Contradict Myself?': Progression through Contraries in Walt Whitman's 'The Sleepers,'” Walt Whitman Quarterly Review 10 (1992), 25-39.

8 One of the most puzzling aspects of "As I Ebb'd with the Ocean of Life" revolves around these "ghoulish" images Lawrence describes. Though noted in the criticism, the graphic descriptions are seldom analyzed in extended readings of the poem. In Disseminating Whitman, Michael Moon does address many of these lines, but he associates them with the father. To Moon, the lines "(See! from my dead lips the ooze exuding at last!/ See-the prismatic colors, glistening and rolling!)" represent the death of the father and of God: "These lines turn the poem back around into its decompositional mode and refocus its religious concerns with death and possible forms of the afterlife; in them, decaying God, dead or dying father, and de-composing poet speak with one voice" (150-151). Kristeva's theory of the abject, however, offers a means to interpret these images and to incorporate them into an extended reading focusing not on the father, but instead on the M/other, a dominant force within the poem.

9 Powers of Horror: An Essay on Abjection. (1980), trans. Leon S. Roudiez (New York: Columbia University Press, 1982). Subsequent references to this text will be cited as Powers.

10 Totem and Taboo in The Standard Edition of the Complete Psychological Works, ed. and trans. James Strachey, 24 vols. (London: Hogarth, 1955), 13:18. Subsequent references to this text will be cited as Totem.

11 Throughout the text, I will use titles from the 1881 edition of Leaves. I will quote lines, however, from the original editions. "As I Ebb'd with the Ocean of Life," initially entitled "Bardic Symbols," was first published in the Atlantic Monthly in April 1860. James Russell Lowell, the magazine's editor, deleted lines 59-60 because of their graphic realism: "(See! from my dead lips the ooze exuding at last!/ See-the prismatic colors, glistening and rolling!)." Whitman acquiesced to Lowell's request but later restored the lines in the 1860 edition of Leaves of Grass. This passage when analyzed in light of Kristeva's theory of abjection takes on particular significance.

12 I will refer to the persona Whitman creates in his poetry as either "the poet" or "the speaker." The use of the term "speaker" does not refer to the subject's state of development. 
13 In 1855 , the poems were not titled. I have used titles from the 1881 edition.

14 Walt Whitman, Leaves of Grass: A Textual Variorum of the Printed Poems, ed. Sculley Bradley, Harold W. Blodgett, Arthur Golden, and William White (New York: New York University Press, 1980). Quotations from Leaves of Grass are from this edition and will be cited parenthetically in the text by line number.

15 A similar pattern occurs in the 1855 poems "Faces" and "Europe." When the poet encounters the abject in 1855 and 1856, it does not repulse him. $\mathrm{He}$ appears, in fact, to embrace it. In 1860, however, he finds no comfort or recompense in the grotesque.

16 Untitled in 1855, "I Sing the Body Electric" became "Poem of the Body" in 1856, augmented with the extensive body catalog from which I quote.

17 Art of Darkness: A Poetics of Gothic (Chicago: University of Chicago Press, 1995), 187.

18 According to Kristeva, one of the earliest stages in recognizing the existence of self as subject is the mirror stage. The young child, for the first time, looks into a mirror and sees himself as whole; at this point, he begins to experience the abject and the materiality associated with the body:

[...] first, the mirror stage, produces the 'spatial intuition' which is found at the heart of the funtioning [sic] of signification-in signs and in sentences. From that point on, in order to capture his image unified in a mirror, the child must remain separate from it, his body agitated by the semiotic motility [. . .] which fragments him more than it unified him in a representation. (Revolution 100)

Kristeva writes that the "semiotic motility" is governed by the chora, a receptacle "nourishing and maternal" but not "unified in an ordered whole" (94).

19 Specimen Days, in Whitman: Poetry and Prose, ed. Justin Kaplan (New York: Literary Classics of America, 1982), 796.

20 Sexual/Textual Politics: Feminist Literary Theory (London: Methuen, 1985), 167. Subsequent references will be cited as Sexual/Textual.

21 "Freud and Love: Treatment and Its Discontents" (1983), trans. Leon S. Roudiez, in The Kristeva Reader, 240-271.

22 Fulia Kristeva (London: Routledge, 1990), 167.

23 Manhood and the American Renaissance. (Ithaca: Cornell University Press, 1989), 3. 
24 Whitman mentions but does not address "fathers" in "There Was a Child Went Forth" and "I Sing the Body Electric," both published in 1855. In desperation, he directly addresses the father for the first time in 1860 in "As I Ebb'd with the Ocean of Life." The plea to the father for acceptance suggests Whitman's anxiety as his work continued, at times, to be the object of public scorn and ridicule. When his country did not embrace him as affectionately as he had embraced it, his dejection manifested itself in his writing. The first lines of the 1860 version of "As I Ebb'd with the Ocean of Life" reinforce Whitman's desire for acceptance: "Elemental drifts! / O I wish I could impress others as you and the waves have just been impressing me" (1-2).

25 Nathanson in Whitman's Presence: Body, Voice, and Writing in Leaves of Grass (New York: New York University Press, 1992) describes the invocation of the father in "As I Ebb'd" as "an ambiguous attempt to revoke the consequences of paternal law" (461). I contend, however, that the paternal invocation is actually a thinly veiled plea for the M/other's embrace. Maternalizing the father suggests the emerging subject's ambiguous response to its inexorable movement towards the Symbolic. His reluctance to separate from the $\mathrm{M}$ /other manifests itself in the maternalized figure of the father: a figure whom the poet addresses as "father" but who has breasts; a figure whom the poet wishes would kiss and comfort him. The ambiguity he experiences rests not with his rejection of "paternal law," as Nathanson contends, but instead with his conflicting emotions of desire for and fear of the M/other.

\section{See notes 5 and 8.}

27 For example, Gay Wilson Allen in The Solitary Singer: A Critical Biography of Walt Whitman (New York: New York University Press, 1967) presents a harsh portrayal of the elder Whitman: "Ordinarily he was taciturn and undemonstrative, but his wife feared his terrible temper when aroused, or-almost as much - his silent spells" (2). By age thirty-four, he had become "soured and irritable" (2). Roger Asselineau in The Evolution of Walt Whitman: An Expanded Edition (Iowa City: University of Iowa, 1999) also writes that Walter Whitman, Sr., was a "hasty and violent man, soured by failure, somber and morose" (25). He concludes that Whitman was probably thinking of his father when he wrote "There Was a Child Went Forth" (18).

28 Walt Whitman: The Song of Himself (Berkeley: University of California Press, 1999), 206. Loving cites Richard Maurice Bucke's biography, Walt Whitman (Philadelphia: David McKay, 1883), a text heavily revised by Whitman himself. Bucke writes that Walter Whitman, Sr., was a "large, quiet, serious man, very kind to children and animals, and a good citizen, neighbor, and parent" (quoted in Loving, 32).

29 The sections Whitman eventually numbers 27, 28, and 29 in "Song of Myself" focus exclusively on the sensual aspects of touch.

30 The Spectral Mother: Freud, Feminism, and Psychoanalysis (Ithaca: Cornell University Press, 1990), 5. 